\title{
ASSESSMENT OF THE USE OF SERVICES IN AGRICULTURE OF THE EU COUNTRIES BASED ON INPUT-OUTPUT TABLES
}

\author{
Malgorzata Kolodziejczak ${ }^{1}$, Ph.D. \\ Poznan University of Life Sciences, Faculty of Economics and Social Sciences
}

\begin{abstract}
As a general economic pattern, the importance of services grows as the economy develops. This is also true for economic processes inside the agricultural sector. The use of services is a measure of modernity, and may substitute capital expenditure. Both the basic research task and the purpose of this paper is to identify the extent of differences in accessing services in the agriculture of EU countries. The study was based on inputoutput tables with a spatial distribution of services by type at country level. As regards the timeframes for this study, the most recent available data from 2000, 2005 and 2010 was used. Over that period, most of the EU countries reported growth of the service sector's contribution to the supply of agricultural materials, which is consistent with the progressive evolution of the agri-food sector. However, between 2005 and 2010, some countries saw a decline in the share of services. This could be caused by the decisions to purchase more efficient, state-of-the-art machinery and equipment which enabled substituting purchased services with own labor. The key services delivered to the agricultural sector were financial, insurance, professional, scientific, technical and veterinary services and, in EU-10 countries, transport services.
\end{abstract}

Key words: agriculture, services, supply of materials, input-output table.

JEL code: L89, Q16

\section{Introduction}

As a general economic pattern, the importance of services grows as the economy develops. This was already noted by the authors of the three sectors theory: List F. (1922), Fisher A. G. B. (1935), Clark C. (1957), Fourastiée J. (1954) and Wolfe M. (1955). This is also true for the processes taking place inside the industrial and agricultural sectors, and is reflected by a gradual growth in importance of supporting services for production processes. Also, the use of services is a measure of modernity (as it becomes the starting point for knowledge, new technology and knowhow transfer), and may be a substitute for capital expenditure (e.g. by allowing to discontinue investments in expensive machinery) and for labour inputs (delivered by farm owners and employees). Therefore, the extent of service use in specific EU countries should be compared to identify the progress of servitization processes in their economies. This paper focuses on the agricultural sector whose condition and structure conditions the continent's capacity to generate food. Also, in broader terms, it strongly affects the use of labour resources throughout the economy and the competitiveness of specific countries. Because services are the determinant of changes taking place in the agricultural sector, they should play an essential role in material flows destined to the agriculture (Mrowczynska-Kaminska, A., Szuba E., 2015), especially having in mind the growing importance of the sustainable growth paradigm.

Both the basic research task and the purpose of this paper is to identify the extent of differences in accessing services in the agriculture of EU countries. The study was based on inputoutput tables where services are considered as a national economy section ${ }^{1}$. The study on the development of service demand was based on a spatial approach, by service type at country level.

\footnotetext{
${ }^{1}$ This study was based on Input-Output Tables data because in the published supply accounts, the supply and use of services are not in balance. A square matrix, the Input-Output Table describes these processes with a product-to-product (or industry-to-industry) mapping, always using the same base. Therefore, a single table includes both the supply and use figures. The essential difference between the definitions of supply-use tables and the Input-Output Table is that the supply-use tables associate products with industries while the Input-Output Table deals with products only. The subject matter of the input-output analysis are the flows between all sectors of the national economy, i.e. the entire process of creating and distributing the national income in quantitative terms over a short term (Mrowczynska-Kaminska A., 2015). Therefore, the Input-Output Table allows to determine, for instance, the volume of services purchased for the agricultural sector from other sectors of the national economy. Input-Output Tables are made every five years in the System of National Accounts (SNA) where production means any activity related to the creation of tangible goods and services (both material and intanib). Until 1995, Input-Output Tab goods and services (both material and intangible). Until 1995, Input-Output Tables were made each year in the Material Product System (MPS)
where production was defined as any activity related to the creation of tangible goods (material production and tangible services) (Kujaczynski T., 2009, Mrowczynska-Kaminska A., 2015).
} 
As regards the timeframes for this study, the most recent available data ${ }^{1}$ from 2000, $2005^{2}$ and $2010^{3}$ were used.

\section{Research results and discussion}

Today's agriculture could not exist without material productive inputs or services such as transport, veterinary and construction services or the machinery and equipment industry (Czyzewski A., Grzelak A., 2009). Each time, production growth contributes to strengthening the following interrelation: on the one hand, the agriculture delivers an increasingly greater volume of raw materials, whereas on the other, it demands increasingly more industrial productive inputs and various types of services (Poczta W., Mrowczynska-Kaminska A., 2004).

The complexity of processes between specific sectors and industries of national economy implies the generation of various types of receivables and liabilities (Czyzewski A., Grzelak A., 2009). Products delivered by specific industries are used as inputs in other ones which otherwise would be unable to perform production activities (Leontief W., 1936, Wos A., 1975, Dietl J., Gregor B., 1977, Tomaszewicz L., 1994, Czyzewski A., 2001, Czyzewski A., 2013, Mrowczynska-Kaminska A., 2015, Poczta W., Mrowczynska-Kaminska A., 2004, Czyzewski A., Grzelak A., 2009, 2012). Therefore, the existence of product flows between industries generates demand for an analysis of inputs and outputs in specific industries and in the economy as a whole (Czyzewski A., Grzelak A., 2009). Agricultural inputs are products manufactured in other sectors of the national economy. Also, agricultural production processes are supported with various types of services, including: logistics, coordination, financing, human labour, technology, information, policies, programs and initiatives (Custodio H. C. Jr., 2003).

The volume of materials supplied to the agriculture primarily depends on the agriculture's importance for the national economy in terms of production capacity and production and income performance (Mrowczynska-Kaminska A., 2009, 2015). This can be noticed by analysing the data shown in Fig. 1. In 2000-2005-2010, the greatest flows from the service sector to the agriculture were recorded in Germany (EUR 6.8-9.1-7.3 billion), France (EUR 4.4-5.1-5.0 billion), UK (2.8-3.8-2.2) and Italy (EUR 2.4-3.0-3.3 billion), followed by the Netherlands and Spain. One-and-a-half times greater than in France, service flows to the German agriculture accounted for around $30 \%$ of total EU-wide material flows from the service sector to the agriculture.

Services, as a determinant of changes taking place in the agri-food sector, play an essential role in material flows destined to the agriculture (Mrowczynska-Kaminska, A., Szuba E., 2015), and are an indirect reflection of its modernity. The service sector had a high share in the flows delivered to the agriculture (Fig. 2) mainly in highly developed countries: Germany, Belgium, Denmark, UK and the Netherlands (18-21\%). In all of these countries, except for Belgium, that share reduced from 2000 (which was largely caused by a certain decline in the use levels of financial services due to the 2007-2008 crisis). Meanwhile, in Belgium, the share of services in material flows to the agriculture more than doubled. Over the period considered, the smallest flows of services to the agriculture were reported in Estonia and Slovenia. In terms of value, they doubled from 2000 to 2010, with a share in the structure of material flows to the agriculture ranging from $8 \%$ to $10 \%$, which is more than in the Polish agriculture. Poland, next to Romania and Finland, demonstrated the smallest share of services in material flows to the agricultural sector.

\footnotetext{
${ }^{1}$ Croatia, Cyprus, Luxembourg, Latvia and Malta are not covered by this study due to lack of comparable data.

2 Data from 2007 are used in the case of the Czech Republic, Denmark, Finland, France, the Netherlands, Germany and Portugal.

3 Data from 2009 are used in the case of Bulgaria and Spain. 


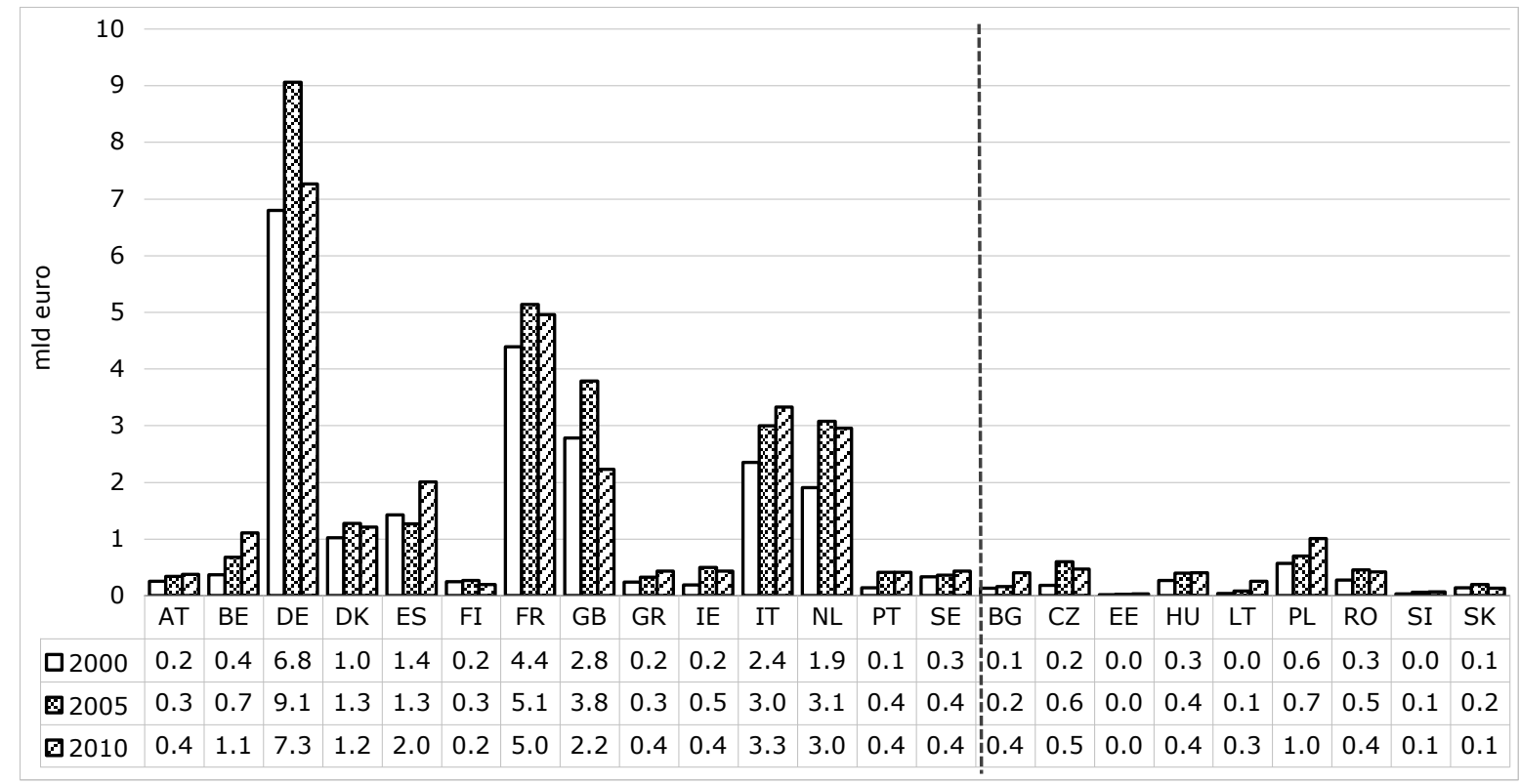

a Country symbols: AT - Austria, BE - Belgium, DE - Germany, DK - Denmark, ES - Spain, FI - Finland, FR - France, GB United Kingdom, GR - Greece, IE - Ireland, IT - Italy, NL - Netherlands, PT - Portugal, SE - Sweden, BG - Bulgaria, CZ Czech Republic, EE - Estonia, HU - Hungary, LT - Lithuania, PL- Poland, RO - Romania, SI - Slovenia, SK - Slovakia. Source: author's calculations based on Input-output table $(2012,2017)$

Fig. 1. Material flows from the service sector to the agriculture in EU countries in 2000, 2005 and 2010'.

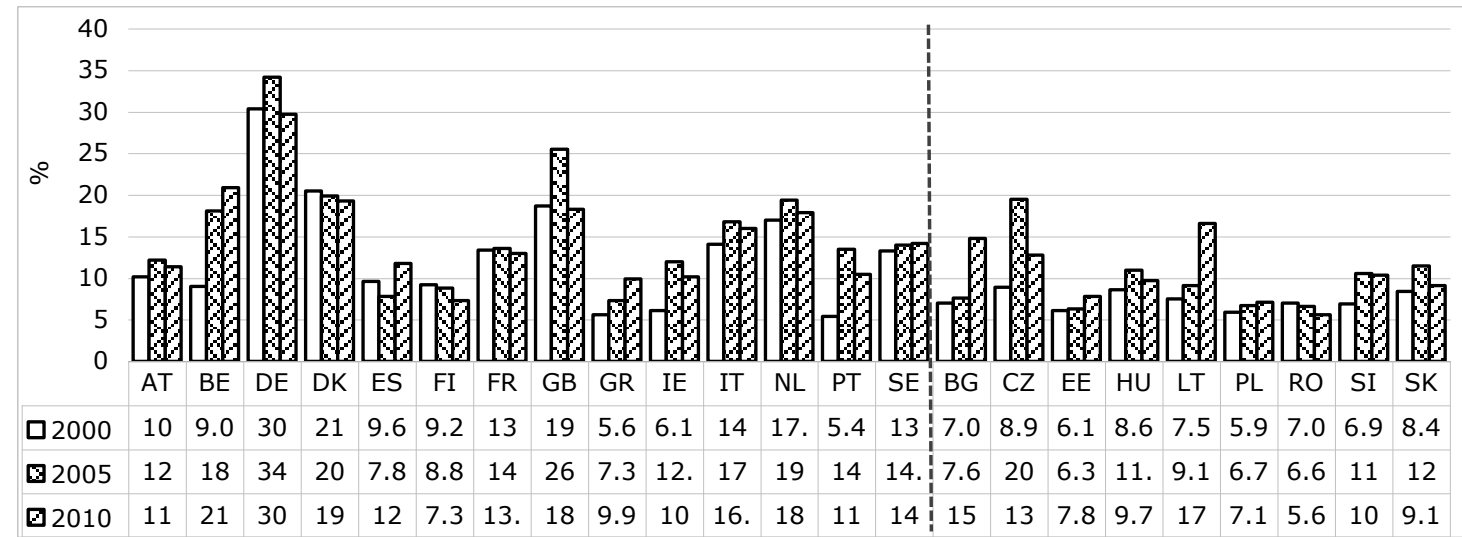

a Country symbols: see Fig. 1

Source: author's calculations based on Input-output table (2012, 2017)

Fig. 2. Share of services in the structure of material flows to the agricultural sector in EU countries in 2000, 2005 and 2010 .

Because of different sizes of economies in countries covered by this study, it is more appropriate to extend the analysis to the internal structure of material flows. Considering the value of service flows to the agriculture sector, three service groups may be identified.

- The first one demonstrates the highest absolute and relative values. It includes financial, insurance, professional, technical and veterinary services.

- The second one is a group of services related to the real estate market, rental and lease, administration services, supporting activities and transport services.

- The third group is composed of all services not listed above.

The highest share of financial and insurance services in the structure of material flows (Table 1) from the service sector to the agriculture was reported in Greece (74\%), Denmark (52 \%) and Sweden (45\%). A large share (above 30 \%) was also recorded in Spain, France, Poland, Finland, Bulgaria and Austria while Romania and Slovakia saw the lowest levels (below $10 \%$ ). In turn, the 
highest shares of professional, scientific, technical and veterinary services were found in Slovenia, the UK, Ireland and Belgium, with Lithuania reporting the smallest shares (6\%). Transport services, services related to the real estate market, rental and lease, administration services and supporting activities had a medium share in the structure of material flows from the service sector to the agriculture. The largest share of transport services of all the countries considered was recorded in Romania and Lithuania (40\%) and in Hungary and Italy (over $30 \%$ ), whereas low levels were characteristic of highly developed Western European countries (e.g. $1.6 \%$ in Denmark). The largest share of services related to the real estate market, rental and lease was recorded in Slovakia and (when combined with administration services and supporting activities) in Germany where the total share of the above services in the structure of material flows from the service sector to the agriculture was $65 \%$. Other service groups were less significant in the mix of services intended for the agriculture. Only the share of information and communication services in Portugal, Estonia, Ireland, UK and Lithuania reached around $10 \%$ (Table 1).

Thus, the key services delivered to the agricultural sector (both in Western European countries and in Central and Eastern European countries) were financial, insurance, professional, scientific, technical and veterinary services and, in EU-10 countries, transport services. The least important set were healthcare and social care services, followed by cultural, entertainment and leisure services, as well as education, accommodation and catering services ${ }^{1}$.

Over that period, most of the European Union countries reported growth of the service sector's contribution to the supply of agricultural materials, which is consistent with the progressive evolution of the agri-food sector. Obviously, that fact does not provide any grounds for making conclusive judgments about the reasons or durability of such changes. At the same time, between 2005 and 2010, some of the countries covered by this study saw a decline in the share of services. Especially as regards Central and Eastern European countries, this could result from extending the Common Agricultural Policy to their agricultural sectors which contributed to increasing the subsidies (payments) ${ }^{2}$ responsible for the growth of the farms' incomes. Another contributing factor was the support in the form of subsidizing certain investment types. As a consequence, the farms started to co-finance the upgrade of their assets with their own funds (including as the required own contribution in investments financed under EU programs). It also resulted in improving occupational safety and enhancing environmental protection. This, in turn, translated into purchases of more sophisticated and more efficient machinery and equipment ${ }^{3}$ which may substitute some services (while stimulating the reduction of overstaffing). At the same time, as noted by Jozwiak W. (2012), the area of intensive crops (which require large quantities of labour and productive inputs per unit area) was reduced, and the downward trend of extensive farming was stopped ${ }^{4}$. Thus, it is not easy to look for reasons which explain the levels of material flows from the service sector to the agriculture and affect their evolution over time. Undoubtedly, service use levels largely depend on the agriculture development level. However, more specifically, both the volume and the structure of material flows from the service sector are developed by multiple measurable and non-measurable variables proper to the economic, natural, social and

\footnotetext{
${ }^{1}$ According to Mrowczynska-Kaminska A., Szuba E. (2015), the increasing importance of financial and insurance services may result from the growing number of the largest farms who rely on external accountancy services.

2 Jozwiak W., Kagan A., Mirkowska Z. (2012).

${ }^{3}$ Cf. Jozwiak W. (2012).

${ }^{4}$ The decline in the number of livestock was also stopped. In 2005-2009, an increase in livestock population was recorded. Jozwiak W. (2012) also states that: a slight increase in intermediate consumption costs indicates yet another striking development. For the agricultural producers, the growing gross margin was a poor incentive to increase their expenditure as a part of intermediate consumption (...) the farming population allocated a large part of funds derived from the gross value added (...) to increased consumption. This was especially true for small farms owned by natural persons.
} 
cultural specifics of each country, and by the related decision-making patterns, production structures and agricultural production management methods.

Table 1

Structure of material flows from the service sector to the agriculture in European Union countries in 2010 by types of activity (\%)

\begin{tabular}{|c|c|c|c|c|c|c|c|c|c|c|c|c|}
\hline Countries & 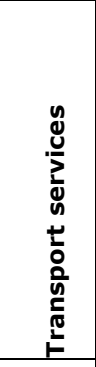 & 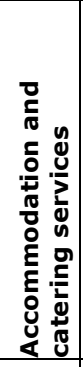 & 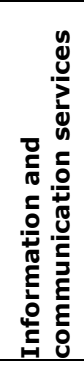 & 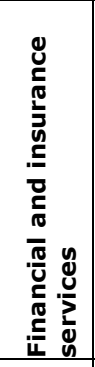 & 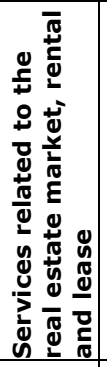 & 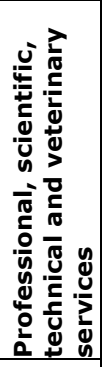 & 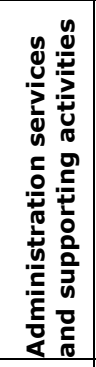 & 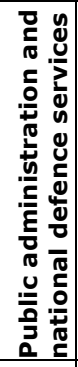 & 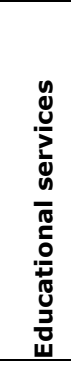 & 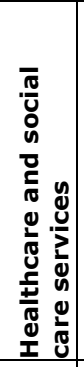 & 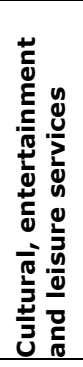 & 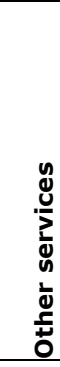 \\
\hline Austria & 8.7 & 1.0 & 3.5 & 30.1 & 17.2 & 35.9 & 2.6 & 0.3 & 0.4 & 0.0 & 0.0 & 0.4 \\
\hline Belgium & 14.5 & 0.8 & 0.5 & 17.9 & 5.3 & 43.5 & 15.1 & 0.1 & 0.0 & 0.1 & 0.9 & 1.2 \\
\hline Bulgaria & 11.1 & 0.1 & 1.5 & 31.6 & 8.3 & 34.3 & 11.8 & 1.0 & 0.0 & 0.1 & 0.0 & 0.2 \\
\hline Czech Republic & 21.2 & 4.6 & 5.9 & 25.2 & 6.4 & 25.1 & 4.7 & 5.7 & 0.8 & 0.1 & 0.1 & 0.3 \\
\hline Denmark & 1.6 & 0.3 & 2.4 & 52.0 & 4.1 & 35.5 & 3.3 & 0.6 & 0.1 & 0.0 & 0.0 & 0.2 \\
\hline Estonia & 25.8 & 0.1 & 8.4 & 17.8 & 10.5 & 29.8 & 1.0 & 1.2 & 0.7 & 0.0 & 0.0 & 4.7 \\
\hline Finland & 8.1 & 2.5 & 4.2 & 32.9 & 15.1 & 22.1 & 4.3 & 6.8 & 0.6 & 0.0 & 0.4 & 2.9 \\
\hline France & 19.0 & 0.6 & 3.2 & 36.7 & 6.9 & 29.4 & 2.1 & 0.0 & 2.1 & 0.0 & 0.0 & 0.0 \\
\hline Germany & 4.2 & 0.0 & 0.6 & 13.9 & 32.7 & 11.4 & 32.1 & 2.9 & 0.2 & 0.2 & 0.0 & 1.7 \\
\hline Greece & 7.5 & 0.0 & 1.6 & 74.1 & 3.2 & 11.7 & 0.1 & 0.0 & 0.0 & 0.0 & 0.0 & 1.7 \\
\hline Hungary & 31.2 & 0.2 & 4.7 & 26.6 & 8.2 & 18.7 & 5.3 & 1.4 & 0.5 & 0.0 & 0.2 & 2.9 \\
\hline Ireland & 7.8 & 0.6 & 8.2 & 28.1 & 4.0 & 45.7 & 0.7 & 0.7 & 0.1 & 0.2 & 1.4 & 2.6 \\
\hline Italy & 30.4 & 1.8 & 2.1 & 27.8 & 4.9 & 25.0 & 2.0 & 0.0 & 0.0 & 0.0 & 0.3 & 5.7 \\
\hline Lithuania & 39.4 & 0.0 & 7.5 & 16.1 & 18.0 & 6.4 & 7.7 & 0.0 & 0.0 & 0.0 & 0.0 & 4.9 \\
\hline Netherlands & 15.7 & 0.3 & 3.3 & 22.7 & 7.2 & 38.1 & 8.0 & 1.9 & 0.5 & 0.0 & 0.1 & 2.1 \\
\hline Poland & 24.7 & 0.3 & 3.0 & 33.5 & 6.0 & 24.7 & 2.7 & 2.6 & 0.2 & 0.6 & 0.1 & 1.4 \\
\hline Portugal & 21.4 & 2.0 & 9.1 & 26.3 & 4.1 & 26.4 & 3.8 & 1.1 & 0.2 & 0.3 & 0.0 & 5.3 \\
\hline Romania & 40.5 & 2.9 & 5.8 & 8.3 & 1.1 & 35.9 & 3.7 & 0.0 & 1.0 & 0.3 & 0.2 & 0.3 \\
\hline Slovakia & 18.4 & 0.1 & 5.7 & 9.1 & 41.0 & 17.6 & 4.6 & 0.3 & 0.1 & 1.9 & 0.2 & 1.0 \\
\hline Slovenia & 7.9 & 0.4 & 0.6 & 28.6 & 1.4 & 59.1 & 0.0 & 0.7 & 0.9 & 0.1 & 0.0 & 0.2 \\
\hline Spain & 15.3 & 0.6 & 2.6 & 38.2 & 0.8 & 22.5 & 16.0 & 0.1 & 1.8 & 1.4 & 0.0 & 0.8 \\
\hline Sweden & 11.7 & 0.9 & 2.4 & 45.3 & 2.6 & 29.0 & 2.3 & 3.7 & 0.0 & 1.0 & 0.0 & 1.1 \\
\hline United Kingdom & 9.4 & 2.0 & 7.8 & 22.7 & 7.9 & 46.5 & 1.0 & 0.4 & 0.4 & 0.1 & 1.9 & 0.0 \\
\hline
\end{tabular}

\section{Conclusions, proposals, recommendations}

1) Over that period, most of the European Union countries reported growth of the service sector's contribution to the supply of agricultural materials, which is consistent with the progressive evolution of the agri-food sector.

2) Between 2005 and 2010, some of the countries covered by this study saw a decline in the share of services. Especially as regards Central and Eastern European countries, this could result from extending the Common Agricultural Policy and support measures (which mean co-financing certain investment types) to their agricultural sectors. This helped making decisions to purchase more efficient, state-of-the-art machinery and equipment which enabled substituting purchased services with own labour.

3) The key services delivered to the agricultural sector (both in Western European countries and in Central and Eastern European countries) were financial, insurance, professional, scientific, 
technical and veterinary services and, in EU-10 countries, transport services. In turn, the least important set were healthcare and social care services, followed by cultural, entertainment and leisure services, as well as education, accommodation and catering services.

4) Undoubtedly, service use levels largely depend on the agriculture development level. However, more specifically, both the volume and the structure of material flows from the service sector are developed by multiple measurable and non-measurable variables proper to the economic, natural, social and cultural specifics of each country, and by the related decision-making patterns, production structures and agricultural production management methods.

\section{Bibliography}

1. Input-output table (2012). Retrieved: http://www.epp.eurostat.europa.eu Access: 20.06.2012.

2. Input-output table (2017). Retrieved: http://www.epp.eurostat.europa.eu Access: 30.09.2017.

3. Clark, C. (1957). The Conditions of Economic Progress. MacMillan, St. Martin's Press, London-New York, p. 720.

4. Custodio, H. C. Jr. (2003). Agribusiness Concepts and Dimension: Some Applications. From C. V. Velasco. Agribusiness Management Course Module. AB 710. Central Luzon State University.

5. Czyzewski, A. (2001). Wspolczesne problemy agrobiznesu w Polsce (Today's agribusiness problems faced by Poland). Wydawnictwo Akademii Ekonomicznej w Poznaniu, Poznań, pp. 5-8. p. 161.

6. Czyzewski. A. (2013). Przeplywy miedzygaleziowe jako makroekonomiczny model gospodarki (Input-output tables as a macroeconomic model). Wydawnictwo Uniwersytetu Ekonomicznego w Poznaniu, Poznań. p. 25.

7. Czyzewski, A., Grzelak, A. (2009). Mozliwosci oceny rozwoju rolnictwa w warunkach globalnych z zastosowaniem tabeli przeplywow miedzygaleziowych (Ability to assess the agricultural development level in a global environment with the use of input-output tables). Zeszyty Naukowe SERiA Volume 11, Issue 2, pp. 43-48.

8. Czyzewski, A., Grzelak, A. (2012). Mozliwosci wykorzystania statystyki bilansow przeplywow miedzygaleziowych dla makroekonomicznych ocen $\mathrm{w}$ gospodarce (Ability to use the balance statistics of input-output tables for macroeconomic assessments). Przeglad Statystyczny, no 1, pp. 173-184.

9. Dietl, J., Gregor, B. (1977). Dysproporcje w rozmieszczeniu produkcyjno-handlowej obslugi rolnictwa (Disproportions in the distribution of production and commercial services for agriculture). Przeglad Geograficzny, Volume XLIX, Issue 4, pp. 657-676.

10. Fisher, A. G. B. (1935). The Economic Implications of Material Progress International Labour Review no 32, pp. 5-18.

11. Fourastié, J. (1954). Die grosse Hoffnung des zwanzigsten Jahrhunderts (The great hope of the twentieth century). Bund-Verlag, Köln-Deutz, p. 320.

12. Jozwiak, W. (2012). Polskie rolnictwo i gospodarstwa rolne w pierwszej i drugiej dekadzie XXI wieku. Konkurencyjność polskiej gospodarki zywnościowej w warunkach globalizacji i integracji europejskiej (Competitiveness of the Polish food economy in the context of globalization and European integration). Program Wieloletni 2011-2014, Warszawa, pp. 119-132.

13. Jozwiak, W., Kagan, A., Mirkowska, Z. (2012). Innowacje w polskich gospodarstwach rolnych, zakres ich wdrazania i znaczenie (Innovations, their implementation scope and importance in Polish farms). Zagadnienia Ekonomiki Rolnej, no 3, pp. 3-27.

14. Kujaczynski, T. (2009). Wykorzystanie bilansu przeplywow miedzygaleziowych do analizy zmian struktur gospodarczych na przykladzie Polski (Using the input-output table balance to analyze the evolution of economic structures as illustrated by the example of Poland). Roczniki Ekonomiczne Kujawsko-Pomorskiej Szkoly Wyzszej w Bydgoszczy, no 2, pp. 93-100.

15. Leontief, W. (1936). Quantitative input and output relations in the economic system of the United States. The Review of Economics and Statistics, no XVIII, pp. 105-125.

16. List, F. (1910). Das nationale System der politischen Oekonomie (The National System of Political Economy). Gustav Fischer-Verlag, Jena, 550.

17. Mrowczynska-Kaminska, A. (2015). Wykorzystanie modelu przeplywow miedzygaleziowych do badania zaleznosci w agrobiznesie w krajach Unii Europejskiej (Using the input-output table model to assess the agribusiness relationships in European Union countries). (In:) Problemy rozwoju rolnictwa i gospodarki zywnosciowej w pierwszej dekadzie czlonkostwa Polski w Unii Europejskiej. A. Czyzewski, B. Klepacki (red.), IX Kongres Ekonomistow Polskich, Wydawnictwo PTE, Warszawa, pp. 80-90.

18. Mrowczynska-Kaminska, A., Szuba, E. (2015). Zmiany przeplywow miedzygaleziowych w rolnictwie nowych krajow czlonkowskich po integracji z Unia Europejska (Evolution of the input-output table in the agriculture of new member countries following their integration into the European Union). (In:) Polska - 10 lat w czlonkostwa w Unii Europejskiej. E. Maluszyńska, G. Mazur, I. Musialkowska (red.). Wydawnictwo Uniwersytetu Ekonomicznego w Poznaniu, Poznan, pp. 143-155.

19. Poczta, W., Mrowczynska-Kaminska, A. (2004). Agrobiznes w Polsce jako subsystem gospodarki narodowej (Agribusiness in Poland as a sub-system of the national economy). Wydawnictwo Akademii Rolniczej im. Augusta Cieszkowskiego w Poznaniu, Poznan, p. 113. 
Proceedings of the 2018 International Conference "ECONOMIC SCIENCE FOR RURAL DEVELOPMENT" No 47

Jelgava, LLU ESAF, 911 May 2018, pp. 149-155 DOI 10.22616/ESRD.2018.017

20. Tomaszewicz, L. (1994). Metody analizy input-output (Input-output analysis methods). Wydawnictwo Naukowe PWE, Warszawa, p. 178.

21. Wolfe, M. (1955). The Concept of Economics Sectors. The Quarterly Journal of Economics. no 69, pp. 402420.

22. Wos, A. (1975). Zwiazki rolnictwa z gospodarka narodowa (Relationships between agriculture and national economy). PWRiL, Warszawa, p. 303. 